\title{
Strengthening the International Financial Architecture: Where Do We Stand? ${ }^{1}$
}

\author{
Barry Eichengreen \\ University of California, Berkeley \\ October 1999
}

It is now nearly two years since Secretary Rubin made his famous speech calling for steps to strengthen the international financial architecture. Unfortunately, this choice of words conjured up visions of an architect's blueprint and a floor-to-ceiling renovation, where this is not in fact how the international financial system evolves. It evolves incrementally, changing on the margin in response to pressures from markets and governments, not discontinuously in response to the radical visions of some economic Frank Lloyd Wright. The existing system is made up of a dense network of social, economic and financial institutions. As with any network (think telecommunications), its components are lent inertia by their interaction, while evolving incrementally in response to technological and other stimuli. So it is, I would argue, with the international financial system.

History supports this interpretation, and the associated prediction. The international monetary and financial system has evolved incrementally from the gold standard to the goldexchange standard, to the Bretton Woods gold-dollar standard and now to the post-Bretton

${ }^{1}$ Prepared for the East-West Center Workshop on International Monetary and Financial Reform, Honolulu, October 1-2, 1999. This paper draws on my previous work, notably Eichengreen (1999a, b). Financial support for this research was provided by the Ford Foundation through the Berkeley Program on International Financial Architecture. Earlier versions were presented at meetings at the East-West Center in Honolulu, the Social Science Research Council in Palo Alto, and the University of California in Washington, D.C.; the comments from participants are acknowledged with thanks. 
Woods system of managed floating. Only in 1944 can it be said that it was radically remade on the basis of an architectural blueprint. And the circumstances then were unique. The prewar system had been discredited. George Soros may have just published a book entitled The Crisis of Global Capitalism, in which he argues that the global financial system is "coming apart at the seams," but his conclusion that the current system should be consigned to the dustbin of history is not widely shared. The prevailing view, as I have put it elsewhere, is that financial markets are worst way of organizing the allocation of resources except for the available alternatives. And even among those who agree on the need for change, there is a striking lack of consensus on the nature of the reforms to be undertaken. Achieving a consensus is immensely more complicated than in 1944 by virtue of the sheer numbers involved. Where in 1944 there were basically one-and-a-half countries at the table, the world today is a more multi-polar place. ${ }^{2}$ This undeniable fact of modern political and financial life greatly complicates the process of reaching agreement.

Finally, it should be acknowledged that proposals to create new international institutions to deal with the crisis problem are politically unrealistic. Our's may be the age of global markets, but it is not an age of global government. There is no appetite for powerful supranational bodies with the power to usurp the traditional prerogatives of sovereign national states. Proposals like Lord Eatwell and Professor Taylor's for the creation of a World Financial Authority must be dismissed as quixotic. $^{3}$ The existing multilaterals -- the Fund and the Bank -- will continue to

${ }^{2}$ This is to say that historians debate the extent to which the United Kingdom provided an effective counterweight to the United States at Bretton Woods.

${ }^{3}$ See Eatwell and Taylor (1999). There are cross currents, to be sure — think of the European Union's institutions of transnational economic governance, or NATO in the Balkans which raise profound questions about the nature of national sovereignty in the $21^{\text {st }}$ century. Still, the reality for the foreseeable future will be one of global markets but national governments. 
possess limited powers.

Given these obstacles to radical reform, those of skeptical temperament will be inclined to ask whether real progress is possible. In this paper I argue that the answer is yes. Initiatives are already underway to strengthen the international financial architecture within the constraints described above. The new international financial architecture is designed to be organized around four pillars: international standards, Chilean-style taxes on short-term foreign borrowing, greater exchange rate flexibility, and collective-action clauses in loan contracts to create an alternative to ever-bigger IMF bailouts. These four elements are designed to strengthen crisis prevention, moderate the severity of crises when they take place, speed the process of recovery, and contain moral hazard in international financial markets. This, in a nutshell, is what the official community means when it talks about strengthening the international financial architecture (Camdessus 1999). My own assessment is that, if these initiatives are pursued to their conclusion, they will succeed in making the world a safer financial place.

The danger is that the process is losing steam. This in turn reflects two developments which are themselves unavoidable aspects of the process of reform. First, these particular reform efforts were identified through an efficient agenda setting by the U.S. Treasury, the G-7, and the IMF. As additional voices are now added to the chorus, the consensus built by the early agenda setters has come under strain. Asian participants and emerging-market participants more generally, having come late to the table, complain that existing blueprints do too little to address the special problems of small nations in large markets. In particular, they fail to adequately address the hedge fund problem. Latin American participants complain that the addition of renegotiation-friendly provisions to loan contracts will raise borrowing costs, making it more 
difficult for them to access the foreign funds needed to deepen their financial markets, reduce their financial fragility, and stimulate their growth. Financial-market participants similarly warn against the disruptive effects of any change.

Second, as time passes, the sense of urgency recedes and second thoughts inevitably develop. Early enthusiasm for greater exchange rate flexibility has become tempered by awareness that more exchange rate volatility can mean less capital-market access. Enthusiasm for Chilean-style holding period taxes to discourage excessive dependence on short-term capital flows is tempered by questions about the scope for evasion and increases in the cost of trade credit. The push for collective-action clauses has been slowed by worries that they can be a source of moral hazard. Enthusiasm for international standards has been weakened by doubts about their effectiveness.

New voices and second thoughts can help to invigorate a stagnant debate, but disputes need to be settled in order to prevent the momentum for reform from being lost. In the social sciences we think that resolution results when there accumulates an overwhelming body of evidence on the effects of alternatives. This may be where academics and the staff of the multilaterals have fallen down. The other message of this paper, then, is the need for more systematic empirical work, and quickly, on the key issues in the architecture debate.

\section{Standards}

The IMF has been criticized for expanding its surveillance and conditionality from the monetary, fiscal and exchange rate policies that are its bread and butter to prudential supervision, auditing and accounting, bankruptcy procedures, corporate governance and competition policy, 
among other issues. Its intrusion into everything from the Suharto family's clove monopoly to Indonesia's national car program is attacked as invasive, unnecessary and counterproductive (Feldstein 1998, Rodrik 1999). It is invasive because it interferes with the traditional prerogatives of sovereign states. It is unnecessary because microeconomic and structural conditions are inappropriate for dealing with currency and financial crises that are essentially macroeconomic in nature. And it is counterproductive because different institutional arrangements are appropriate for different economic, legal and cultural settings and because ignoring this runs the risk of provoking a populist backlash.

The counter-argument is that high capital mobility makes it impossible to fix the international financial system without also fixing the domestic financial systems of countries active on international markets. International financial stability requires domestic financial stability, given the propensity for financial problems to spill across borders. And domestic financial stability can only be attained through institutional reform. This is problem with Feldstein's conclusion that the IMF should stick to giving advice on monetary and fiscal policies and not meddle in the other internal arrangements of countries. Stabilizing a country's financial system requires institutional reforms extending well beyond policies toward external trade and payments. Few would question that creating a stable financial environment presupposes disclosure requirements for banks and corporations to make available the information required for market discipline to work, and prudential supervision to compensate for the shortcomings of banks' and firms' own risk-management practices. In a world where financial crises can spread contagiously, the international community has a common interest in seeing that all countries active on international markets adopt minimally-acceptable domestic arrangements in these areas. 
Some will argue that this is as far as the IMF and the international community should go in intruding into countries' internal affairs. I find it impossible to resist concluding that they must go further -- that the need for domestic institutional reforms with implications for the stability of international financial markets extends beyond this point. It extends to the use of internationallyrecognized auditing and accounting practices, in whose absence lenders will be unable to accurately assess the financial condition of the banks and corporations to which they lend. It extends to effective creditor rights, in whose absence claimants will be unable to monitor and control the economic and financial decisions of managers. It extends to investor-protection laws to prevent insider trading, market cornering and related practices, in whose absence securities markets will not develop. It extends to fair and expeditious corporate bankruptcy procedures, without which debt problems can cascade from borrower to borrower. Countries can satisfy these desiderata in different ways, but in a world of capital market integration there is no avoiding the need to satisfy them.

The fear is that international pressure for reform will force all emerging markets to don what Thomas Friedman (1999) has dubbed the "golden straitjacket," denying them all opportunity to design regulatory institutions responsive to their distinctive economic, cultural and legal traditions. This is where standards come in. Standards, which define criteria to be met by all countries but permit them to satisfy them in different ways, offer a way of reconciling the common imperatives created participation in international markets with the diversity of economic systems and structures. The complaint that the IMF's structural interventions are arbitrary and capricious at least partly explains the backlash they have provoked; with the promulgation of standards there will exist an objective set of criteria to which the Fund can refer when it demands structural 
reforms.

Designing international financial standards is a complex and multi-faceted process. It must proceed on many fronts, reflecting the extent to which the international financial system itself is multi-faceted. The IMF has taken the lead in this process, issuing a series of Experimental Studies on Transparency and attempting to coordinate its own standards-related initiatives with those of the World Bank, the Basle Committee, and various private-sector bodies. ${ }^{4}$ As a result it has become evident that neither the IMF nor the official community as a whole possesses the human resources necessary to design and monitor compliance with detailed international standards in all the relevant areas. In its experimental studies, the Fund has been forced to rely on self-evaluations by the subject countries, a practice which compromises the objectivity of the process. For the Fund to carry out this function in a satisfactory way would require a very significant increase in its staff and a radical change in expertise, which are unlikely for the foreseeable future. ${ }^{5}$

This means relying as heavily as possible on the private sector: on the International Accounting Standards Committee, the International Federation of Accountants, the International Organization of Supreme Audit Institutions, Committee J of the International Bar Association, and the International Corporate Governance Network, among others. Most of these selforganizing bodies have emerging-market members; some have subcommittees expressly concerned with issues of concern to emerging markets. The multilaterals should of course

\footnotetext{
${ }^{4}$ These documents would more accurately be labeled "Experimental Studies of Standards." That "transparency" instead appears in the title reflects the fact that British officials, who were first to push the idea of annual IMF reports in this area, used the transparency moniker.

${ }^{5}$ See the discussion of resource implications in IMF (1999).
} 
participate in the deliberations of these bodies as a way of taking "ownership" of the standards they set. But the private sector must take the lead. While the IMF and the other multilaterals can take on some standard-setting responsibilities themselves -- witness the Fund's Special Data Dissemination Standard and Codes for Monetary and Fiscal Policies -- the bulk of the work will have to take place elsewhere. This may already be the case for standard setting, but it is not yet true of compliance evaluation. My own idea (Eichengreen 1999a) is that each self-organizing body should be encouraged to rate countries' compliance with their standards and to establish an electronic bulletin board on which to post this information. Hyperlinks should be provided to the Fund's own electronic bulletin board (as they already are, to a limited degree, for macroeconomic and financial data). Where the self-organizing committee is comprised of national regulators, the rating function could still be privatized; it could be spun off to commercial concerns like FitchIBCA, Moody's and Standard \& Poor's.

Do the self-organizing bodies, or for that matter the rating agencies, have adequate incentive to stay on top of the task? Given the checkered record of the latter, there are real questions about the adequacy of their evaluations. In the end it may be necessary for the IMF to take on the compliance-evaluation function itself. The best way of doing so would be by publishing an annual report in which it rated each of its member's compliance in each of the relevant sub-areas (perhaps in conjunction with its annual or biannual Article IV consultations, and with help from the World Bank and the BIS). This is what the Fund's aforementioned Experimental Studies in Transparency are designed to do. But these studies do not include the kind of blunt ratings that effective evaluation requires. There are no bullet points akin to those for capital-account liberalization that appear in the Fund's Exchange and Trade Restrictions Annual. 
If the Fund is to reserve compliance evaluation for itself, then it will have to take the hard decision to move in this direction.

Lenders having a limited attention span, the IMF will in any case have to reinforce market discipline by offering the carrot of concessionary interest rates on its loans to countries that comply and by conditioning its programs on steps to bring national practice into conformance. It has taken a first step in this direction by specifying compliance with a range of transparencyrelated standards as a prerequisite for qualifying for its newly-established Contingent Credit Facility. Unfortunately, at the time of writing no country has deemed it worthwhile to apply for a Contingent Credit Line. Moreover, the Articles of Agreement do not appear to permit differential interest rates for countries meeting different standards. Fixing this problem would require some fast footwork on the part of the Legal Department, or amending the Articles of Agreement. ${ }^{6}$

Notwithstanding wide international backing, reservations have been expressed about how much can be accomplished through the promulgation of international standards. There is widespread disagreement about the definition of acceptable standards - observe the dispute between the U.S. and Europe over accounting standards or the wide variation among the advanced-industrial countries in the provisions of bankruptcy and insolvency codes. There is the danger that an international standard broad enough to encompass these variations will tend toward a lowest common denominator. Moreover, standards, by defining the minimum acceptable threshold, may weaken the incentive for countries to do better. What will prevent

${ }^{6}$ Another potential step in this direction, to be adopted not by the Fund but by national regulators, has been suggested by the Basle Committee, whose proposal for revising the 1988 Capital Accord would key the risk weights on international lending to the compliance of the capital-importing countries with a range of financial standards (Basle Committee 1999). It is yet to be seen whether this idea features in any ultimate revision of the Accord. 
governments from taking steps to meet the letter of the requirement in fact satisfying its spirit?

Such qualms are reinforced the experience with the most important experiment in standard setting to date, the Basle Capital Standards. The 1988 Capital Accord established an eight per cent minimum (weighted) capital adequacy standard for international banks. It deserves some credit for steps taken subsequently, by countries represented on the Basle Committee of Banking Supervisors and others, to bring capital adequacy up to this minimum. Reassuringly, the existence of the Basle Accord has not prevented countries like Argentina from doing better. But, at the same time, the Basle standard has been subject to evasion. The gap between the reported and actual capital of Japan's international banks is notorious, and the Basle Accord did nothing to head off or resolve the Japanese banking crisis. Banks have discovered ways of shifting assets subject to high capital charges off balance sheet through securitization and the use of complex derivatives without modifying the underlying risks. This should serve as a warning of the danger that the standard setters will always be one step behind the markets. Finally, experience with the 1988 Capital Accord points up the fact that poorly-designed standards, or standards that lag behind circumstances, can create perverse incentives. One need only recall the incentive in the 1988 Accord to engage in short-term lending to non-OECD countries. ${ }^{7}$ Observers of the Asian crisis will be aware of the consequences.

Perhaps the most fundamental critique of this push for standards is that it is based on the dubious notion that stabilizing markets requires additional regulation. Many of the aforementioned standards (for prudential supervision, bank capitalization, etc.) are meant as

${ }^{7}$ While lending to OECD banks was given a risk weight of 20 per cent irrespective of the term of the loan, lending to non-OECD banks carried this reduced weight only for loans of less than a year, whereas loans of longer maturity carried the full 100 per cent risk weight. 
guides for regulation. They are designed to identify minimally acceptable levels of regulation for all countries active on international financial markets. Yet experience with the Basle capital standard creates real reasons to think that the regulators will always be one step behind the markets. This is why alternative approaches to prudential supervision, like requiring banks to issue uninsured subordinated debt, are gaining ground in the United States. The solution to the financial-instability problem, it is argued, lies in strengthening market discipline - in the present context by creating a constituency of subordinated debt holders who stand to gain nothing for additional risk taking and are likely to be especially averse to exceptional losses — not in adding additional regulation. This has led some to dismis the entire standard-setting enterprise is misguided.

This critique is too strong. Many of the standards on which the international policy community is focusing are designed precisely to strengthen market discipline. This is the case for auditing, accounting, public disclosure of corporate and financial balance sheets, and corporate governance generally; their purpose is to strengthen the information provision and creditor rights without which market discipline cannot be effective. Whether one believes that the emphasis should be placed on government regulation or market discipline, standards are the way to proceed.

\section{Exchange Rates and the Capital Account}

The single most reliable leading indicator of crisis risk in emerging markets (maybe the only reliable leading indicator) is short-term external debt, the short-term external debt of the 
banking system in particular. ${ }^{8}$ Short-term debt is liquid, and if investors choose to liquidate it, serious financial problems can arise. When the debt in question is debt of the banking system, whose assets are relatively illiquid (by definition, since banks are in the business of providing liquidity-transformation services to information-impacted segments of the economy), the result can be bank runs and banking crises. The consequences are especially disruptive in latedeveloping countries, where the informational prerequisites for securitized markets are missing and banks dominate the market in intermediation services.

Capital requirements can apply appropriate incentives on both the borrowing and lending sides, although there are reasons to worry about their effectiveness in politicized environments where capital is all too rarely written down, and given the scope for regulatory arbitrage. Holding-period taxes a la Chile can also be used to lengthen the maturity structure of the debt. There is an enormous debate over the effectiveness of these taxes. Some critics insist that evasion remains a problem. Others observe the lack of evidence that Chile's taxes limited the overall level of foreign borrowing. The second objection can be dismissed on the grounds that the goal was never to limit the overall level of foreign borrowing but to alter its average maturity, and on the maturity front the evidence is compelling. As for the first objection, it is important to recall that such a measure, in order to lengthen the maturity structure of the debt, need not be evasion free. For the time being, the last word on this issue goes to Chile's finance minister, who has asked (I

${ }^{8}$ To be sure, saying that short-term debt is a useful leading or concurrent indicator is different from saying that it plays a causal role in financial instability. The accumulation of shortterm debt may simply be a manifestation of other economic and financial problems in whose presence countries will find it impossible to roll over their maturing long-term loans and find it impossible to avoid accumulating short-term external liabilities (Eichengreen and Hausmann 1999). Thus, in economic analysis — as opposed to forecasting — it is important to distinguish alternative sources of the accumulation of short-term debt. 
paraphrase), "If these capital-import taxes are so easily evaded, then why do we have so many non-interest-bearing foreign deposits at the central bank?" But better pinning down the effects of these policies should be a high priority for empirical work. ${ }^{9}$

The other way of discouraging banks and corporates from developing excessive dependence on short-term, unhedged foreign debt is by pursuing policies of greater exchange rate flexibility. Allowing the exchange rate to fluctuate is the only credible way of encouraging agents to hedge their exposures. A pegged rate provides an incentive for the private sector to accumulate unhedged foreign debts. To defend the peg, the government is forced to insist that there is no prospect that it will change. How many chief financial officers will then be rewarded before the fact for purchasing costly exchange-rate insurance on currency forward and futures markets? If the currency is allowed to fluctuate on a day-to-day basis, banks and firms will learn the importance of purchasing insurance against currency swings. Then, when the exchange rate does move by an unexpectedly large amount, they will not be thrust into bankruptcy by the increase in the cost of servicing short-term foreign debts. A currency crash will not automatically mean a financial crash, as it did for example in Indonesia in 1998, and the greater stability of the domestic financial system will in turn stabilize the exchange rate.

While this was the consensus of first-generation contributions to the architecture debate, opinion has been swinging back in the other direction. Skeptics argue that greater exchange rate variability means less access to foreign capital, which in turn means shallower financial markets,

\footnotetext{
${ }^{9}$ A start has been made by Calvo and Reinhart (1999), who find in a 15 country panel, including Chile, that the presence of capital controls is significantly associated with a lower share of portfolio plus short-term capital flows as a percentage of total flows. That they do not find the same when they look at portfolio flows alone suggests that the impact on short-term flows is doing most of the work.
} 
greater financial fragility, and slower growth. ${ }^{10}$ A fluctuating currency makes it less attractive for foreign lenders to lend, especially in the currency of the borrowing country. Capital flows, especially short-term portfolio capital flows, are less. This is apparent in the strikingly low correlation of savings and investment in particular regions of larger countries, in contrast to the much higher correlations for countries as a whole. Another way to putting the point is that a fluctuating (or potentially fluctuating) currency which discourages foreign investors from lending in the currency of the borrowing country also limits the ability of banks and firms to hedge their foreign-currency exposures in the aggregate. They can reshuffle those exposures so as to avoid dangerous concentrations, but the overall level of foreign-currency exposure is given. Greater exchange rate flexibility which creates an incentive to hedge these risks shows up in a lower level of foreign borrowing.

Indeed, if the costs as well as the benefits of hedging rise with exchange-rate volatility, more volatility will not necessarily mean more hedging. In currency forward and futures markets, where there is uncertainty about whether the counterparty will be able to deliver on the contract, costs can be sharply rising. Markets in currency hedges are insurance markets, and, as in any insurance market, adverse selection can interfere with the tendency for the quantity of insurance to rise with the underlying risk. As the risks go up, it may pay to buy and sell less. Combining the greater risks due to currency volatility with the increased cost of purchasing insurance cover suggests that the reduction in unhedged exposures will be achieved through a fall in the level of borrowing and lending.

Thus, greater exchange rate variability may reduce crisis risk, but it may also slow

\footnotetext{
${ }^{10}$ See Hausmann, Gavin, Pages-Serra and Stein (1999)
} 
economic growth in countries whose development strategies depend on capital imports. Some may therefore want to go all the way in the other direction, to dollarization, to obtain freer access to capital flows. But making dollarization work requires putting in place supportive conditions. The banking system must be strengthened to compensate for the absence of a lender of last resort. The budget must be balanced to compensate for the reduced scope for the central bank to backstop the market in public debt. Otherwise, dollarization may only convert currency crises into financial crises.

The interesting question, familiar to observers of European monetary unification, is whether such reforms must be put in place prior to abandoning the domestic currency, which implies that this solution to the currency conundrum will not occur anytime soon, or whether they can be induced by an early shift to dollarization. The proponents of early dollarization would argue as follows. Abandoning a national currency for the dollar will bring down interest rates by eliminating currency risk, thereby strengthening the fiscal position (as in countries like Ireland, Portugal, Spain and Italy in Stage II of the Maastricht convergence process). Moreover, to the extent that the weakness of banking systems in emerging markets reflects currency and maturity mismatches that inevitably arise when a country has a weak national currency, the definition of a weak currency being an inability to borrow abroad in domestic-currency terms (hence the currency mismatches) and to borrow at home long term (hence the maturity mismatches), dollarization, by eliminating these constraints, will strengthen the banking system. Dollarization need not wait on prior reform, in this view, because it delivers that reform.

Even if this is the case, the number of emerging markets that are willing to pursue this alternative is likely to remain few. The story would be different were it possible for Mexico or 
Argentina to obtain a seat on the Federal Reserve Board and influence the stance of their common monetary policy. But the day when the United States is prepared to grant Mexico or Argentina a seat on the Open Market Committee, or even extend U.S. bank regulation and limited lender-of-last-resort services to the country, is still very away. Monetary unification may be the vision of the future, but more flexible rates are the reality for today.

\section{Bailing in the Private Sector}

Ensuring greater private-sector burden sharing has proven to be immensely complicated, making it one of the sticking points in efforts to strengthen the architecture. Initiatives along these lines are motivated by the perception that IMF programs starting with Mexico have let private investors off the hook and are therefore a source of moral hazard. In addition, because the Fund is almost always paid back, these payoffs to investors are effectively transfers from the taxpayers of the crisis country to the international financial community.

In thinking about the problem, it is important to emphasize two points. First, what has worked before is unlikely to work again, due to changes in market structure and circumstances. Second, we should be cautious of rules-based approaches to bailing in the private sector. The problem is that this may only precipitate additional crises, as the markets anticipate the authorities' response and scramble out the day before.

The most widely-cited instance of bailing in the private sector was at the end of 1997 , when bankers and officials canceled their Christmas and New Year holidays in order to negotiate a debt rollover for Korea. The country's maturing bank loans were renewed (typically for an additional 90 days) and subsequently converted into bonds, averting a full-fledged financial 
meltdown. There is the question, of course, of whether this was actually an instance of private sector burden sharing, since the banks didn't "take a hit" (in fact they were compensated generously for their forbearance). Equally important, however, is whether this approach can be used again in the future. There are reasons for thinking not. For one, future debt will not be bank debt to the same extent. The securitization of claims is ongoing: bond debt has risen from about 20 per cent of total non-official credit to emerging markets in 1990 to 70 per cent in 1997 . There will be more holders of these securities (hedge funds, pension funds, insurance companies, and individual investor), making it harder to bring the players to the table. Moreover, not all other countries will have recently-elected democratic governments with a reformist mandate, which in Korea encouraged the banks to stay in. Not all other countries will have fundamentally-strong economies affected mainly by liquidity problems and well positioned to bounce back subsequently. Finally, the sovereign guarantee the Korean government provided first to the domestic banks and then the bonds into which the bank credits were converted, which also reassured investors, was viable only by virtue of the sovereign's light debt load, an advantage that not all governments will enjoy.

Efforts to arrange private-sector burden sharing for Ukraine and Pakistan in late 1998 and early 1999 are more informative insofar as these cases involved mainly securitized debts. In Ukraine the securities in question were a 375 million hryvnia ( $\$ 90$ million) tranche of treasury bills falling due on September $22^{\text {nd }}, 1998$, which the country found impossible to roll over due to the Russian crisis. The IMF then arranged a $\$ 2.2$ billion credit, of which $\$ 257$ million was made available immediately. But to prevent its disbursement from being used to pay off private creditors, the Fund set a target for exchange reserves, conformance with which effectively 
prevented the Ukrainian government from paying back these bills in hard currency. The government pressured the creditors to restructure (to exchange their treasury bills for longer-term zero-coupon eurobonds) and payed investors who resisted in local currency which could be used to purchase goods and services domestically but could not be repatriated.

While this is a straightforward way of bailing in the bondholders, it is not without risk. When a country is declared to be in default, the bondholders can sue, triggering cross-default clauses in the country's other debt instruments and requiring immediate repayment. In Ukraine's case, reassuringly, the creditors did not sue. But before concluding that the Fund should employ this approach more widely, it is worth noting respects in which Ukraine's situation was special. The debts in question were domestic-currency-denominated securities, not eurobonds, which are effectively regarded as senior by the markets. And the bonds in question were governed by Ukrainian law, rendering legal recourse unattractive.

Pakistan's case involved eurobonds. The country was driven to consider renegotiating them, along with its much larger debts to official creditors, by a combination of domestic economic problems and the disruption to its market access following its tests of nuclear devices in May 1998 and did so through the Paris Club. In the context of the negotiations a country undertakes in the Paris Club for debt relief from its official creditors, it is normal practice for the government to be required to seek comparable treatment from its private creditors. Typically, the private creditors of Paris Club supplicants have been banks (whose credits are renegotiated through the London Club), not bondholders, since low-income countries with an overhang of official debts have found it understandably difficult to borrow on the bond market. Thus, the inclusion of bonds in the comparability provision of Pakistan's Paris Club Minute is precedent 
setting.

However, this case is again not representative of the situation in which many other countries will find themselves. Pakistan's eurobonds are British-style instruments which can be restructured subject the approval of only a majority of the holders, not unanimous consent as is the case with American-style bonds. This limits the likelihood that a restructuring agreement will precipitate legal action.

This brings us to the case for amending loan contracts to include sharing clauses, majority voting clauses, and minimum legal threshold clauses. It is worth restating how this idea fits into the architecture debate. A credible commitment by the IMF not to automatically run to the rescue of a country that would otherwise find it impossible to keep current on its obligations presupposes the existence of a viable mechanism for dealing with problem debts. It is easy to say that the Fund should not automatically bail out governments and their creditors, but it is hard for it not to do so as long as there do not exist other way of reasonably addressing financial problems when they arise. The shortcoming of existing arrangements is that they make workouts excessively difficult. Since many international bonds include provisions requiring the unanimous consent of bondholders to the terms of a restructuring agreement, there is an incentive for "vultures" to buy up the outstanding debt and threaten legal action. Unlike syndicated bank loans, most such bonds lack sharing clauses requiring individual creditors to share with other bondholders any amounts recovered from the borrower and thereby discouraging recourse to lawsuits.

Those who believe that countries may have to take occasional recourse to suspensions and restructurings argue that these provisions in bond covenants should be modified. Majority voting 
and sharing clauses would discourage maverick investors from resorting to lawsuits and other ways of obstructing settlements beneficial to the debtor and the majority of creditors alike. Collective-representation clauses, which specify who represents the bondholders and make provision for a bondholders committee or meeting, would allow orderly solutions to be reached. This was suggested in 1996 by the G-10 in its post-Mexico report and echoed in a series of recent G-22 and G-7 reports and declarations. The G-7 then placed the issue on its work program for reforming the international financial system with the goal of reaching a consensus by the Cologne Summit in June of 1999.

The objection to this idea is that it would raise the cost of borrowing by making it too easy for countries to walk away from their debts. Collective-action clauses would weaken the bonding role of debt. They would create moral hazard. They would disrupt credit-market access.

The counter-argument is that provision for orderly restructurings would make emergingmarket issues more attractive by minimizing acrimonious disputes, unproductive negotiations, and extended periods when no service is paid and growth is depressed by a suffocating debt overhang. As The Economist put it in a leader, "the prospect of an orderly renegotiation rather than a messy default might actually make some bonds more attractive" (Economist 1999, p.21).

The analogy with domestic bankruptcy procedures supports this more optimistic interpretation. Presumably, few of the critics would argue that countries should abolish their bankruptcy laws and reinstitute debtor's prison to discourage borrowers from walking away from their debts. Rather, they acknowledge the need in the domestic context for balancing measures designed to strengthen the ex ante bonding role against the efficiency advantages of ex 
post procedures to efficiently restructure problem debts. They may still object that recent proposals move too far from the first end of the spectrum to the second: it could be that, given the legal immunity sovereign borrowers enjoy and the special legal difficulties of seizing the assets of foreign borrowers in general, collective-action clauses would seriously weaken the bonding role of debt. But this is an empirical question.

Unfortunately, it is one that has been informed by little empirical analysis. This is disappointing insofar as there already exists a market in London on which "British-style bonds" incorporating collective-action clauses are issued. Comparisons of the spreads on these bonds with spreads on otherwise equivalent "American-style" bonds are an obvious way of evaluating the afore-mentioned arguments.

Upon reflection it becomes apparent that the comparison is not straightforward. Not only does one have to control for observable borrower characteristics and market conditions affecting emerging-market spreads, but the choice of governing law is likely to be endogenous and depend on the issuer's characteristics. Borrowers who anticipate the need to restructure may be attracted to instruments that anticipate this eventuality, as will lenders who value quick resolution. Alternatively, borrowers thought likely to default on their obligations may incur the greatest surcharge if they issue a loan with collective-action provisions, encouraging them to opt for bonds that exclude these clauses. Thus, while the possibility of bias due to the endogeneity of the choice of governing law cannot be ignored, not even its direction is clear.

Indeed, not just the costs of funding but the very ability of developing-country borrowers to access the market may be affected by collective-action clauses. High-risk borrowers, far from just being charged more for contracts including these provisions, may not be able to obtain loans 
at any price. Alternatively, if collective-action clauses increase borrowing costs, they may cause high-quality borrowers to quit the market. Either way, the implication is that even estimates of the effect of choice of governing law on spreads that control for the endogeneity of the choice of governing law will still be contaminated by selectivity bias. Any attempt to infer the impact of collective-action clauses on borrowing costs from the existing pool of borrowers would still be biased insofar as the composition of that pool could change with the introduction of those provisions.

This does not mean that it is impossible to analyze the impact of collective-action clauses on emerging-market spreads, only that this must be done using a framework that takes these problems into account. Eichengreen and Mody (1999) attempt to do just that. Looking at all international bonds issued in the 1990s for which the relevant information is available (approximately 2,000 bonds), we find that the choice of governing law (UK, which generally includes collective-action clauses, versus New York, which does not) has a negligible impact on borrowing costs, as if the advantages of orderly resolution and the disadvantages of moral hazard offset. But when we disaggregate by credit worthiness, sharper results emerge. Issuers from countries with high credit ratings pay significantly lower spreads on bonds issued under UK law. In contrast, issuers from countries with low credit ratings feel the opposite effect. These findings are intuitive. The most credit worthy borrowers will go to the wall to avoid having to suspend service on their debts. (Think of South Korea and the implications of its geopolitical alliance with the United States for its attitude toward the maintenance of debt service.) For credit-worthy countries, the moral-hazard effect is negligible. The advantages of orderly restructuring in the event of truly extraordinary events beyond the control of the country are attractive to investors, 
who take up the bonds in question at lower spreads. For countries with less sterling credit, in contrast, moral hazard remains a concern, perhaps the dominant one. For them, collective-action provisions that weaken the bonding role of debt result in higher spreads.

So while mandating collective action clauses in bond contracts might make life more difficult for less creditworthy borrowers, it should make life easier for the more credit worthy. This is a reminder of the dangers of lumping together all emerging markets whether the issue is architecture or another topic. But if one of the goals of architectural reform is to encourage the markets to better differentiate among borrowers and more generously reward efforts to improve credit worthiness, then mandating the inclusion of collective-action clauses in loan contracts becomes more attractive. And for those concerned with distribution and with the welfare of the least credit-worthy countries, it suggests the need to marry this kind of architectural reform to other initiatives (like debt relief) expressly tailored their problems.

More generally, the backward-looking, case-by-case approach relied upon so far by the IMF and the U.S. Treasury to bail in the private sector fails to meet minimally acceptable standards for clarity, transparency and equity. The international policy community is experimenting on small countries whose default is unlikely to threaten systemic stability, which may be prudent from a systemic point of view but is hardly equitable. Insofar as these countries are special, bailing in the private sector hardly constitutes the kind of useful precedent the "bailers" wish to set. It would be better to devote less of the international community's scarce political capital to backward-looking efforts to deal with these special cases and more to forwardlooking efforts to amend loan contracts. 


\section{The Hedge Fund Problem}

The hedge-fund problem has attracted considerable attention in Asia and elsewhere. It is important to recognize that this is not just a bee in Mr. Mahathir's bonnet. Official reports from countries other than Malaysia (viz. Reserve Bank of Australia 1999) have argued that hedge fund operations in their markets have considerably aggravated volatility. While such allegations can be disputed, given how little public information is available about hedge fund trades and positions, they deserve to be taken seriously.

The most important point about hedge funds is how little is special about them. Hedge funds are highly leveraged, but so are investment banks and other financial institutions. They take short positions in assets markets, but so do other investors. They utilize exotic and "plain-vanilla" derivative securities, but so do other market participants. They move in and out of emerging markets, but so do mutual funds, commercial banks, investment banks and a variety of other financial entities. One can argue that hedge funds are more flexible, more aggressive, or more predatory, but given the extent to which their capital is swamped by, say, the proprietary trading desks of investment banks, their impact on market outcomes is easily swamped as well.

Consider, for example, the issue of leverage. George Soros has testified to the U.S.

Congress that the Quantum Funds are leveraged by a factor of 2 to 3. This is typical of the macro funds surveyed by Hennessee Associates, MAR/Hedge, and other consulting firms. According to MarHedge, a third of hedge funds do not use leverage at all, and fewer than one in six lever their assets more than twice. Such simple measures of leverage are highest for market neutral-arbitrage 
funds, since the volatility of an unlevered market-portfolio would normally be low. ${ }^{11}$ Macro funds use moderate leverage on average: nearly 70 percent claim to lever their capital less than two times. To be sure, one can question the accuracy of such generalizations. The survey data on which they are based are provided voluntarily and not verified independently. However, US Government (1999) reports, on the basis of mandatory Commodity Pool Operator (CPO) filings with the CFTC, that as of September 1998 it was aware of only ten hedge funds with on-balancesheet leverage of more than ten to one, and one hedge fund with leverage of more than 30 to one. ${ }^{12}$ The omission of off-balance sheet items, which may be particularly important for certain classes of hedge funds, may lead their leverage to be understated. That said, banks would still appear to be even more leveraged than hedge funds as a group. The typical gearing ratio for commercial banks is on the order of ten to one, while the ratio of total assets to equity, or gross leverage, for the top investment banks ranges from 25 to 35 (the ratio of gross assets excluding matched-book financing to equity, or net leverage, ranges from 10 to 25). ${ }^{13}$ Admittedly, investment banks and other institutional investors have more diversified portfolios; they are

\footnotetext{
${ }^{11}$ This is, of course, the category in which LTCM is traditionally placed. This suggests that some hedge funds with exceptionally high investment to capital ratios may be lurking in the survey returns referred to above. LTCM normally leveraged its capital 20 to 30 times; the much higher ratios circa September 1998 that were reported in the press reflected the extraordinary losses of capital following Russia's default.

${ }^{12}$ No extra credit for guessing the one hedge fund with an exceptionally high leverage ratio. Unpublished data from Hennessee Associates suggests that 12 per cent of all hedge funds had leverage ratios greater than eight to one at the end of 1998, including 8 per cent of macro funds, 33 per cent of emerging market funds, 25 per cent of technology funds, and 71 per cent of distressed securities funds. I thank Lee Hennessee for this information.

${ }^{13}$ As reported in International Monetary Fund (1998). The five largest commercial bank holding companies had average leverage ratios of 14 to 1 at the end of 1998 according to US Government (1999).
} 
unlikely to concentrate their positions in particular markets. ${ }^{14}$ But their capital is orders of magnitude larger, so even a small portfolio share can swamp the entire hedge fund industry.

Hence, changing the way hedge funds are regulated or forcing them to disclose information about their operations would change nothing from the emerging-market point of view. To be sure, hedge funds have played a prominent role in a certain emerging-market crises; the IMF's hedge fund study pointed to Thailand as an example. ${ }^{15}$ But given the growing international activities of other institutional investors including not just investment banks but also commercial banks, mutual funds and pension funds, the instances where hedge funds dominate conditions in individual emerging markets are likely to be even less common in the future than the past. Tighter regulation of hedge funds would change little in terms of aggregate market outcomes. $^{16}$

This has not stemmed the flood of reports on the industry from, inter alia, the BIS, the U.S. Treasury, the Federal Reserve Board, the Securities and Exchange Commission, the Commodity Futures Trading Commission and, soon, the Financial Stability Forum. Some of their suggestions are uncontroversial. To whit: supervisors should better monitor the exposure of their banks and nonbank intermediaries to hedge fund counterparties, since a failure of a major hedge fund counterparty like Long-Term Capital can threaten systemic stability; and the Basle Capital

${ }^{14}$ As argued by Reserve Bank of Australia (1999), p.5.

${ }^{15}$ Eichengreen and Mathieson et al. (1998). Yam (1999) and Grenville (1999) similarly conclude that they moved markets in Hong Kong and Australia in 1998.

${ }^{16} \mathrm{~A}$ recent piece on hedge funds in the New Yorker Magazine, of all places, by the financial journalist John Cassidy makes exactly this point. As Cassidy puts it, hedge funds are not the problem, investment banks are. 
Standards should be amended to require capital surcharges for lending to counterparties (including hedge funds) that do not disclose information on their balance sheets and positions. In addition, the U.S.-German proposal for a "credit registry" to assemble in one place national regulators' data on their banks' exposures to highly-leveraged institutions could be usefully revived. One of the major problems uncovered in the course of the LTCM crisis was that U.S. regulators knew the exposure of U.S. banks to LTCM, while Swiss regulators knew the exposure of Swiss banks to LTCM, but they did not know the exposure of one another's banks or the overall degree of leverage acquired by the firm, and hence the risk it posed to systemic stability. Creating mechanisms for effective information sharing is the obvious solution. ${ }^{17}$

The most radical report on the hedge fund issue to date is that of the Joint Task Force of the US President. It recommends that hedge funds registered as CPOs, and which therefore are obliged to report to the CFTC, should be made to file more comprehensive reports on a quarterly (rather than an annual basis), and that this information should be made public. Funds that are not registered as CPOs should be required to disclose similar financial information, presumably also on a quarterly basis. Financial institutions, for their part, should be required to disclose a summary of their exposure to hedge fund counterparties.

While this push for disclosure is understandable, serious doubts can be raised about its efficacy. First, will quarterly reports be a significant improvement over annual reports, given the speed with which hedge funds put on and take off positions? Would a report for the second quarter of 1998 made available to the public in the third quarter have provided significant advance

${ }^{17}$ To be sure, there is danger that information pooling will remain partial, and that information pooling not accompanied by adequate information analysis will create a dangerous sense of complacency. But these are useful cautions, not reasons to reject the credit-registry idea. 
warning of the difficulties of LTCM to the regulators or have headed off subsequent difficulties through the operation of market discipline? This seems unlikely.

In addition, requiring additional disclosure may simply lead hedge funds to relocate offshore. The task force therefore recommends that offshore financial centers adopt and comply with internationally-agreed upon standards for disclosure and prudential supervision. Recommend it can, but the problem of offshore financial centers and tax havens is of long-standing. ${ }^{18}$ From this point of view, the recommendation that regulators (and the Basle Committee) apply tougher capital standards on counterparty transactions for banks doing business with financial entities offshore that do not comply with the Basle Core Principles is useful, there is again the danger that any such initiative would be neutralized by regulatory arbitrage.

Then there is the question of whether there is justification for additional public disclosure. The Task Force appears to believe that public disclosure will strengthen market discipline on hedge-fund counterparties (as opposed to hedge funds themselves, on which few members of the public hold claims). This proposition is as dubious as the mechanism is indirect. The case for additional disclosure to regulators is strong, but that for additional disclosure to the public is weak.

How then should the hedge fund problem be addressed? For regulators concerned with systemic stability, there is no alternative to tightening up oversight of hedge fund counterparties. Regulators responsible for seeing that banks and other credit providers stay on top of the operations of their hedge-fund customers should continue to scrutinize these functions in the

\footnotetext{
${ }^{18}$ At the time of writing, it is being studied by another working group of the Financial Stability Forum.
} 
course of the normal supervision process. In addition, regulators should more systematically share information on the exposure of the intermediaries for which they are responsible. For developing countries concerned with the potential for large hedge funds to destabilize small markets, the available options are entry and exit taxes to discourage the kind of short round-trips in which hedge funds engage, and more flexible exchange rates to avoid offering the one-way bets hedge fund managers find so appealing. Neither policy offers fool-proof protection against threats to market integrity, but these are the only instruments whose costs do not exceed their benefits.

\section{Regional Funds}

The idea of an Asia Fund to supplement the IMF was advanced by the Japanese Government following the outbreak of the Asian crisis and has been developed further by various academics and officials. ${ }^{19}$ Three rationales for the approach can be usefully distinguished. While I discuss them here in the Asian context, the implications are more general.

First, peer pressure may work better at the regional level. Europe, where mutual surveillance has a long history and a procedure by that name has been enshrined in the Maastricht Treaty, is frequently cited a case in point. But in contrast with Europe, Asia (and other regions) lack institutions with track records comparable to those of the EU's Monetary Committee and Ecofin Council. Nor do Asian countries appear ready to negotiate an international treaty which makes provision for serious sanctions and fines like those of the Maastricht Treaty for countries that fail to adjust their domestic policies. More fundamentally,

\footnotetext{
${ }^{19}$ See for example Ito, Takatoshi, Ogawa and Sasaki (1999).
} 
Asia lacks the tradition of integrationist thought and the web of interlocking agreements that encourage monetary and financial cooperation in Europe. There is no counterpart to the social and political "pillars" of the Maastricht Treaty to support the application of peer pressure. There is no wider web of political and diplomatic agreements to be placed at risk by a failure to cooperate on monetary and financial matters.

Second, because economic structures and conditions vary by region, neighboring countries have a comparative advantage in diagnosing their distinctive economic problems and crafting appropriate solutions. All Asian economics have bank-based financial systems and highly-geared corporate sectors, which the IMF overlooked, the argument goes, when prescribing interest-rate hikes to deal with the crisis; an Asian Monetary Fund would not have committed such an egregious error. This seems to me to exaggerate structural similarities within the region. It is hard to think of three more structurally different economies than Japan, Indonesia, and China, for example.

Third, and related to the preceding, it is argued that the creation of regional monetary funds will intensify competition in the market for ideas. If countries in crisis could appeal to both the IMF and a regional monetary fund, whose assistance was conditioned on different policy actions, then a genuine market in ideas would develop, and only institutions giving sound advice would be able to retain a customer base. If it has a poorer understanding of the roots of the Asian crisis and what measures should be taken to address it than experts employed by the Asia Fund, the IMF will lose business to its regional competitor.

Unfortunately, the analogy with market competition is questionable. In a competitive economy, the firm with the best ideas produces the best product, makes the most profits, and 
ends up dominating its market. It is not clear that the same is true of the market in policy advice and official financial assistance. Intergovernmental organizations do not behave like profitmaximizing firms. A multilateral that offers inferior advice does not necessarily end up losing market share and "filing for bankruptcy." The IMF is paid before other creditors whether its advice is good or bad. It does not follow that a regional fund which lent to governments at unrealistically low interest rates would be driven out of business, since it would more likely than not have its coffers replenished by the high-income countries that were its principal shareholders.

Thus, while the idea of regional funds to supplement the crisis-prevention and crisismanagement functions of the IMF has intuitive appeal, closer scrutiny raises serious questions about the approach.

\section{Changing the Governance of the IMF}

My book on architecture is subtitled "A Practical Post Asia Agenda." Given that focus, I have been criticized for not offering more ambitious, far-reaching proposals. While officials need to be practical, the critique goes, academics should be provocative and ambitious. This paper therefore closes with an ambitious scheme..$^{20}$

A problem with IMF decision-making, in the view of many critics (emerging-market critics in particular), is that it is excessively politicized. Excessive weight tends to be attached to national interests, interfering with the IMF's ability to pursue its global mandate. It has been argued, for example, that several of the Fund's recent programs, like those for Mexico, serve the

\footnotetext{
${ }^{20}$ Due to De Gregorio, Eichengreen, Ito and Wyplosz (1999).
} 
interests of creditor countries by providing financial assistance that allowed foreign portfolio investors to be repaid at the expense of the taxpayers of the crisis country. Here the implication is that IMF policies were used to advance creditor interests, at the expense of creating moral hazard and at considerable cost to the Mexican taxpayer. It is similarly argued that the U.S. Government arm-twisted the Fund into agreeing to continued disbursements for Russia in 19978, despite evidence that economic and financial reform there was off track, in an effort to prop up what it perceived as a reform-minded government and out of concern that failure would bring to power extremists who could not be trusted with the country's nuclear capability. Again, the implication is that IMF policies were used to further U.S. security objectives rather than in the pursuit of financial stability, aggravating moral hazard rather than furthering reform. It is argued that the conditionality the Fund attached to its Asian programs, requiring the crisis countries to open their financial markets and distribution systems to foreign competition, served the interests of advanced-industrial countries seeking market access more than the crisis countries themselves.

If the problem is that the Fund's decisions are distorted by the parochial concerns of national governments, then greater independence from those governments is the logical solution. The obvious way of achieving this is by amending the Articles of Agreement to enhance the independence of the Executive Board. Executive Directors could still be appointed by national governments or groups of governments, just as central bank governors in some federal systems are appointed by state or regional governments. But if Directors are too inclined to take advice from those governments, then the Articles should be amended to discourage them from doing so. If the Statute of the European System of Central Banks prohibits members of the ECB Board 
from taking advice from their governments, in other words, why shouldn't the IMF's Articles of the Agreement impose the same prohibition on Executive Directors?

Effective independence may require amending the Articles to appoint Directors to multiyear terms of office and to create high hurdles to their dismissal. Their independence will be strengthened if they receive adequate compensation. ${ }^{21}$ It may be desirable to include a provision barring them from moving laterally into government or finance for a specified period following their term on the Board. True independence may in addition require budgetary independence. All large international rescue packages in the 1990s have been cobbled together out of contributions from the IMF, other multilaterals, and national governments. Given the rapid expansion of international liquidity, IMF resources alone have not been enough. The Fund's dependence on financial supplementation from national governments would be another check on the institution's independent Directors. It may be desirable therefore to amend the Articles of Agreement to give the Fund the option of borrowing on the market, subject to the concurrence of a supermajority of the Board (see also Lerrick 1999).

The danger with such reforms is that they would vest too much power in an all-powerful board of monetary technocrats. This could be addressed by amending the Articles to give Directors an explicit mandate and by insisting on greater transparency, notably by requiring more decisions to be taken on the basis of up-or-down votes and releasing the results. In addition, Directors should be required to explain their decisions, and the substance of Board discussions should be made public. If Directors have idiosyncratic objectives, greater transparency of decision making will reveal their hidden agendas, which will in turn strengthen

\footnotetext{
${ }^{21}$ History suggests that this should not be a problem.
} 
their incentives to pursue the Fund's mandate. Directors' ultimate constituencies will then be able to judge whether their representatives supported or resisted a particular Fund policy, and Directors, rather than going along to get along, will have an incentive to register their dissents. Ultimately, a specific body must have the power to hold the Executive Board accountable. The obvious candidate is the Interim Committee (soon to be transformed into the International Monetary and Financial Committee, by a decision of the IMF Executive Board). Individual Directors or even the entire Board could be dismissed by a supermajority vote of the Interim Committee. The French Government among others has suggested vesting additional power with the Interim Committee as a way of reinvigorating the Fund. ${ }^{22}$ Making provision for the Interim Committee to hold Directors accountable is a way of achieving this without politicizing the activities of the Fund.

More than a few readers be inclined to dismiss this proposal as unrealistic. Perhaps. But who could have imagined a few years ago how many countries would have moved to establish independent central banks? In an age when some observers call for abolishing the IMF and other recommend creating a "true international lender of last resort," enhancing the independence of its Board is a limited reform. For those who recognize that financial markets are imperfect and acknowledge that those imperfections create the need for an institution to backstop the markets, but who at the same time worry that national agendas too often distort IMF decision making, this is a logical way to proceed.

\footnotetext{
${ }^{22}$ Related proposals were included in the G7 Finance Ministers' Cologne Summit Report on Strengthening the International Financial Architecture.
} 


\section{Where We Stand}

Official efforts to strengthen the international financial architecture are organized around four pillars: international standards for financial management and regulation, Chilean-style taxes on short-term foreign borrowing as a form of prudential regulation to be imposed until countries have brought other forms of banking-sector supervision up to world-class levels, greater exchange rate flexibility for the majority of emerging-market economies, and collective-action clauses to create an alternative to ever-bigger IMF bailouts. All four elements would have to be adopted to make the world a safer financial place. The good news is that all four elements are on the agenda. Each of them has been embraced by either the United States or other countries. The bad news is that not all four elements have been embraced by both the United States and other countries.

International standards are one element on which everyone agrees, although much remains to be done to ensure effective monitoring and adequate incentives to comply. The United States has endorsed greater exchange rate flexibility for emerging markets and the use of Chilean-style capital-inflow taxes. But it is still reluctant to do more than utter some encouraging words to bring about the introduction of collective action clauses into loan agreements. Unfortunately, without the addition of renegotiation-friendly provisions to loan contracts, the IMF cannot credibly promise to stand aside when a country is pushed to the brink. And if the IMF cannot credibly refuse to organize a financial rescue, then the incentives for emerging markets to adopt greater exchange rate flexibility and taxes on short-term capital inflows will remain weak.

European policy makers, for their part, are even more concerned about private sector burden sharing. They are less reluctant to require the introduction of new provisions in loan contracts. But given their own experience, they are less understanding of the need for exchange 
rate flexibility. And the same is true of Asia, where there continues to be talk of a yen bloc based on basket pegs with common weights for the countries of the region, the disastrous experience with pegs in the first half of the 1990s to the contrary notwithstanding. Without greater exchange-rate flexibility, the temptation to engage in excessive short-term foreign borrowing will remain, and the adverse financial consequences of large exchange-rate changes, when they come, will be all the more devastating. Again, asserting that the IMF could simply stand aside and let events play themselves out is not credible.

Thus, while constructive steps have already been taken to strengthen the international financial architecture, the new table on which the system will rest remains rickety. It has at best three legs, not four. And without all four legs, stability will be lacking. 


\section{References}

Basle Committee on Banking Supervision (1999), “A New Capital Adequacy Framework," Basel (3 June), http://www.bis.org/press/index/htm.

Calvo, Guillermo A. and Carmen M. Reinhart (1999), "When Capital Inflows Come to a Sudden Stop: Consequences and Policy Options," unpublished manuscript, University of Maryland at College Park.

Camdessus, Michel (1999), "Address by Michel Camdessus to the Board of Governors of the Fund,” Washington, D.C. (28 September), http://www.imf.org/external/np/speeches/1999/ 092899/HTM.

De Gregorio, Jose, Barry Eichengreen, Takatoshi Ito and Charles Wyplosz (1999), An Independent and Accountable IMF, Geneva Report on the World Economy 1, London: CEPR (forthcoming).

Eatwell, John and Lance Taylor (1999), "Capital Flows and the International Financial Architecture," unpublished manuscript, New School for Social Research.

Economist (1999), “Sovereign Policy,” Economist Magazine (13 February), p.21.

Eichengreen, Barry (1999a), Toward a New International Financial Architecture: A Practical Post-Asia Agenda, Washington, D.C.: Institute for International Economics.

Eichengreen, Barry (1999b), "Policy-Making in an Integrated World: From Surveillance to...?" In Federal Reserve Bank of Boston, Policy-Making in an Integrated World, Boston: Federal Reserve Bank of Boston.

Eichengreen, Barry and Ricardo Hausmann (1999), "Exchange Rates and Financial Fragility," in Federal Reserve Bank of Kansas City, Issues in Monetary Policy, Kansas City: Federal Reserve Bank of Kansas City (forthcoming).

Eichengreen, Barry and Donald Mathieson (1998), Hedge Funds and Financial Market Dynamics, Washington, D.C.: International Monetary Fund.

Feldstein, Martin (1998), "Refocusing the IMF," Foreign Affairs 77, pp.20-33.

Friedman, Thomas (1999), The Lexus and the Olive Tree, New York, Farrar, Straus, Giroux.

Grenville, Stephen (1999), "Financial Crises and Globalisation," unpublished manuscript, Reserve Bank of Australia, htt://www.rba.gov.au/speech/sp_dg_150799.html. 
Hausmann, Ricardo, M. Gavin, C. Pages-Serra and E. Stein (1999), "Financial Turmoil and the Choice of Exchange Rate Regime," unpublished manuscript, Inter-American Development Bank.

Hernandez, Leonardo and Klaus Schmidt-Hebel (1999), “Capital Controls in Chile: Effective? Efficient? Endurable?" unpublished manuscript, Central Bank of Chile.

International Monetary Fund (1999), "International Standards and Fund Surveillance — Progress and Issues," Washington, D.C. (16 August), http://www.imf.org/external/np/rosc/stand.htm.

Ito, Takatoshi, Eiji Ogawa and Yuri Nagataki Sasaki (1999), "Establishment of the East Asian Fund," Chapter 3 of Institute for International Monetary Affairs (ed.), Stabilization of Currency and Financial Systems in East Asia and International Financial Coordination, Tokyo: Institute for International Monetary Affairs.

Reserve Bank of Australia (1999), "Hedge Funds, Financial Stability and Market Integrity," paper submitted to House of Representatives' Standing Committee on Economics, Finance and Public Administration's Inquiry into the International Financial Markets' Effects on Government Policy (June).

Lerrick, Adam (1999), Private Sector Financing for the IMF: Now Part of an Optimal Funding Mix, Washington, D.C.: The Bretton Woods Committee.

Rodrik, Dani (1999), “Governing the Global Economy: Does One Architectural Style Fit All?” unpublished manuscript, Harvard University.

Rodrik, Dani and Andres Velasco (1999), "Short-Term Capital Flows," unpublished manuscript, Harvard University and New York University (April).

Rubin, Robert (1999), "Remarks on Reform of the International Financial Architecture to the School of Advanced International Studies," Treasury News (21 April), RR-3093.

Soros, George (1998), The Crisis of Global Capitalism, New York: Public Affairs Press.

Yam, Joseph (1999), "Capital Flows, Hedge Funds, and Market Failure: A Hong Kong Perspective," paper presented to the Reserve Bank of Australia Conference on Capital Flows and the International Financial System, Sydney, 9-10 August. 